\title{
Exploring the city as text and dominant discourse place
}

\author{
Mojtaba Valibeigi \\ Buein Zahra Technical University, Qazvin, Iran, mojtaba.valibeigi@bzte.ac.ir
}

\begin{abstract}
The study has tried to answer the question of how the dominant discourse in the city tries to create meanings and forms an interpretation by using signs and symbols. Accordingly, common semiotics of Dur Untash city has been investigated. In three steps, including preparation, organization, and final report or conclusion, a content analysis method has been done. First, deconstruction views of reading place are explained and how an interpretation discourse is formed. Then we investigated some standard semantic features of Dur Untash city and an image of some familiar ideas and signs is projected. Finally, a bipolar semantic interpretation of these signs and images is presented. The dominant discourse of the city has wanted to catch a meaning, but none of its symbols and characters has such a valid capacity and authority. Therefore, the dominant discourses could not conjure spatial features controlled by meaning-making
\end{abstract}

Keywords: reading place, landscape interpretation, the city as text, the dominant discourse

\begin{abstract}
Abstrak
Penelitian ini mencoba menjawab pertanyaan bagaimana wacana dominan di kota mencoba menciptakan makna dan membentuk interpretasi dengan menggunakan tanda dan simbol. Dengan demikian, semiotik umum kota Dur Untash telah diselidiki. Dalam tiga tahap, termasuk persiapan, organisasi dan laporan akhir atau kesimpulan, metode analisis isi telah dilakukan. Pertama, penjelasan dekonstruksi pandangan tempat membaca dan bagaimana wacana tafsir terbentuk. Kemudian peneliti menyelidiki beberapa fitur semantik umum kota Dur Untash dan memproyeksikan gambar dari beberapa ide dan tanda umum kota. Akhirnya, interpretasi semantik bipolar dari tanda dan gambar ini disajikan. Wacana dominan kota ingin menangkap makna, tetapi tidak ada simbol dan rambu-rambu yang memiliki kapasitas dan otoritas yang valid. Oleh karena itu, wacana-wacana yang dominan tidak dapat memunculkan ciri-ciri spasial yang dikendalikan oleh pembuatan makna.
\end{abstract}

Kata Kunci: membaca tempat, intrepetasi lansekap, kota sebagai teks, wacana dominan

Received: 2020-04-23 | Accepted : 2020-07-05 | DOI: 10.29080/eija.v6i1.894 | Page: 1 - 10

EMARA: Indonesian Journal of Architecture

http://jurnalsaintek.uinsby.ac.id/index.php/EIJA

This article is open access distributed under the terms of the Creative Commons Attribution

ShareAlike 4.0 International License, which permits unrestricted use, distribution, and

reproduction in any medium provided the original work is properly cited.

\section{Introduction}

Deconstruction shows a complex response to a theoretical variety and very prominent philosophical movements in 20th century as the phenomenology of Husserl, de Saussure, Ferdinand, French structuralism and Lacan psychoanalysis and how the plural logic emerges from out of the relative ruin of the transcendental tradition (Hurst, 2008; Sellers, 2003). It shows the fact that any radical shift of interpretative thought must always come up against the limits of seeming absurdity. Philosophers have long had to recognize that thinking may lead them inescapably into regions of scepticism such that life could scarcely carry on if people were to 
act on their conclusions (Norris \& Roden, 2003). Also, deconstruction can be seen in part as a vigilant reaction against this tendency in structuralism thought to tame and domesticate its own best insights. Some of Jacques Derrida's most influential essays are devoted to the task of dismantling a concept of 'structure' that serves to immobilize the play of meaning in a text and reduce it to a manageable compass (Norris \& Roden, 2003).

All concepts are contradictory for Derrida. Suppose sentences in language are indefinite and therefore conflicting. In that case, the idea of the sentence is contradictory, since the sentence must both be what takes meaning and what cannot take meaning. The sentence cannot be isolated as a meaning unit from its context so that it does not exist in a stable self-identical way, as the same sentence may have different meanings in different contexts. The sentence must be what it is and not what it is. This is the same applies to all aspects of meaning. The contradiction is sharper in the Derrida's account than in the Ludwig Wittgenstein account, where contradiction arises implicitly from the variable context of sentences. There is no escape from the paradox in Derrida through looking at the different possible meanings as different usages in other clearly individuated language games, which is one way of reading Wittgenstein to effort the exclusion of contradiction (Wittgenstein, 2010). The idea of different language games does not exist in Derrida, and even in Wittgenstein, they overlap so that the possibility of contradiction cannot be ignored. All sentences are necessarily contradictory in Derrida's account because they both mean and do not mean according to a specific meaning contained within the sentence that shapes it (Lacey,
2002; Richter, 2010; Staten, 1986; Stocker, 2006).

Deconstruction considers how philosophical texts, when setting the definition as the starting point, do not pay attention to this fact that all these behaviours which led to the description, have an inner order, the order in which everything has been defined due to what was not before it (Evans, 1991; Wood \& Bernasconi, 1988). Derrida is part of a sceptical tradition; However, Derrida is not a sceptic in the strict sense. The intense feeling of scepticism must contain at least two points: first, the complete denial of knowledge of reality itself, usually because no knowledge allegations have assurance guaranteed certainty; second, in the sense that we deny a large part of what is taken as evidence of the nature of reality, and this sceptical movement is often followed by the constructive action in which something better is offered as evidence of fact (Naas, 2003; Stocker, 2006; Williams, 2001).

In the text that its foundation is broken, the superiority of one meaning than the opposite one disappears. Accordingly, the text is multi- meanings; and because of countless interpretations, the final meaning has been lost (Bennington \& Derrida, 1993; Freshwater \& Rolfe, 2004; Payne, 1993; Wood, 1992). Derrida showed that all texts are based on dual orders, such as existence/nonexistence, man/woman. Where the first member of each group is considered as meaning and have a preference, in all those sources of thought, there is a hypothetical vantage core or an Archimedean point. Just that theoretical vantage core was placed on deconstruction sights, useless and nonhierarchical of that was revealed, and what was considered constant and logical, became unreasonable and void. The interpretation by itself contains many 
misconceptions (Lagasse, 2003). The purpose of the research is exploring the city as text and dominant discourse place by focusing on the city of Dur Untash and how its spatial features could not conjure textual functionality as controlled by its symbols and sings.

\section{Method}

This study used a qualitative content analysis method in reading the city as text. In analyzing the qualitative content, by examining signs and symbols, we attempted to comprehend urban landscapes and reveal their dominant discourse. Using deductive logic, we did it in three steps of preparation, organization and reporting. In the preparation step, the deconstructive perspective on text and symbol analysis is examined first. In the organizational step, semantic features of Dur Untash city and an image of its ideas and signs are brought together, and in the final stage, the interpretation and report of these symbols are presented based on the deconstructionist perspective.

Content in content analysis refers to any document that indicates the relationship between human beings. Therefore, the paintings engraved in caves, music, books, articles, manuscripts, postcards, movies, etc., we call content. Accordingly, content analysis is a method of analyzing qualitative studies by which data is summarized, described, and interpreted. When researchers intend to test or verify the validity of a theory, model, or hypothesis, they use a deductive content analysis (Anandarajan et al., 2018; Kyngäs et al., 2019). Accordingly, since this study seeks to investigate the validity of deconstruction theory in the field of urban semantics, we used the method of deductive content analysis. We chose the first cities as a text.

\section{Result and discussion}

\section{Step 1: deconstruction and reading} place

Urban semiotics shows the joint of ideology and power structures with human urban space, and analysis propose the investigation of public imagination and meaning code articulated with space (M. Gottdiener \& Lagopoulos, 1986; Pipkin et al., 1983). Accordingly, social semiotics has a key role in the recognition of public understanding in looking to space that including social connotations (Keller, 1988). Consequently, space is known when symbolic meaning and complex impact on human behaviour have been recognized, and space has potential for combining geographic and social imagery with all complexity (Harvey, 1970, 2010). There is an essential principle in art and architecture that spatial forms can be applied in different ways; in this way, is induced various symbolic meanings. If the city contains signs and symbols, then the purpose of these symbols can be understood by people; we should try to understand the sense that people receive from their built environment (Knox, 1984). The urban space is not only a face of the economic and political power which put on different times by various societies; it is also a means by which the dominant structure of power and socio-economic relationships are continued (Gieseking et al., 2014). Accordingly, the city as text defines a language written by a built world and known by its citizens through cognitive imaging (Barthes, 1968, 1994). So, what kind of meaning is linked to the city and by what kind of mechanism? (Krampen, 2013). These are a crucial role in the interpretation of urban semantics.

What the city is looking for, what people and different social groups are looking for in the city, are the creation of meanings and differentiation. Meanings and differentiations result from mental 
and social processes and power structures-a prominent interpretation that we would like to accept and internalize; an idea which roots in desire. The city is trying to induce and create it, but from deconstruction's view, any symbolism in order to build it both in individual or social authority level is doubtful. By frustrating urban meanings, deconstruction is trying to eradicate the boundary between opposite concepts and see it as one-dimensional ones. Based on the perspective, there are two types of cities: the first city was formed by the authority of that time and understood and interpreted on this basis. And its logic and truth can be found; everything in it has been reduced to the double contradictions like persistence/instability, real / nonreal.

Whether it is a dominant and authoritative interpretation of urban symbols or critical interpretation, an understanding of authority structures and social processes can be investigated. Depending on the interpretation, it was understanding the symbolic meaning of space to be subject to a certain single unit idea. Refer to the general idea, spatial meanings are understood. What makes sense of the concepts of superiority, control, domination, authority, exploitation, and so on through the game of social contracts and social hierarchies. But it also has the second city, which is freed from the double contradictions; the logic and truth cannot be found in it, and with the roots destructing of its symbolic meaning, does not have mean, and the first city is the sign for this second city.

In other words, when we want to interpret the city in terms of a symbolic function; since city acts at the symbolic level, affected of social process and authority; works on the action of repeating something that has already been said or extends overt to cover partly, provide to experience a change in form or phenomenon or be a concise version of something, has become internally differentiated (Abbinnett, 2003; D'Cruz, 2016; Gabriel, 2013; Wood, 2012). So symbol, semantics and authority interpretation make an inner dominant aspect when placed in a deconstruction interpretation are became bipolar.

\section{Step 2: semantics of Dar Untash landscape}

The city as the first form of civilization and the centre of holiness, power and wealth always has been an ideal and sacred meaning. It has tended to portray its sociophilosophical aspirations towards the future and its destination that led to the emergence of different ideals (Morris, 2013; Nas, 2016; Seasoltz, 2005). Several studies have shown the decisive impact of the subject of the worldview on genesis city of Dur Untash and its life centre (Ghirshman, 1961; Rohl, 1999). Valuing and sacred markings in the city, naturally have guarantee and continuity mechanisms that can re-generate or vice versa can eliminate and degradation semantic loads over time. Dur Untash were created as symbolic centres of ceremonies. Thus, the city is a symbol of the world, and it has the power to organize and regulate more expansive areas (Bryce, 2009; Osborne, 2014; Potts, 2006). Generally, the city has the fundamental principles to refers: The centre of the world being against subordinate; a manifestation of perfection and divine order in contrast to the external world's disorder; Eternal presence and stability versus instability, mortality. The city is recognized and validated according to a series of holy ceremonies such as many early first cities and the city, and its religious buildings are built based on a philosophy that comes from the beliefs of men. And this creates a 
critical interpretation of the structures of power and social processes of domination and a deconstruction of the cause of the tendency toward forms in historical trend.

The ancient Choga Zambil site is located at 48 and 30' minute's longitude, and $32^{\circ}$ latitude in Khuzestan and the southeastern part of the Shush city and is located on the part of Taghdis Sardarabad of Zagros Mountain Range. The Elamite ruler Untash-Gal built the ancient city of Dur Untash or the historical site of Choga Zambil in the 13th century BC during the Middle Elamite period (c. 1500-c. 1000 BCE)(Britannica, 2018). The city's spaces separated by three concentric walls, in which in the centre of them there is an elevated temple or so-called Ancient Temple, "ziggurat ". The temple was given to two of the great Elamite gods, Inshushinak and Napir. Choga Zambil's ziggurat is the same holy buildings in which elements of thought blend with holiness are seen. The Choga Zambil's ziggurat is a multi-story building, squareshaped that first floor is more extensive and wider than the upper floors. There are circular walls around this square-shaped building that is a remembrance of the combination of squares and circles in this sacred building (see fig1) (Fisher \& Shivers, 2008).

In this respect, the Choga Zambil's ziggurat is similar to the Kaaba's home. Kaaba's house is a black building and square-shaped (cubic) that Muslims go around circular the Kaaba with the white ihram clothes. The Square-shaped building of Choga Zambil with Circular fences is reminded the number four as a sacred number in architecture. Four in the ancient is a symbolic numeral like the four rivers in paradise that are cross-shaped; four sections of the earth, and so on. From the farthest ages, four was used to represent what is robust, tangible and sensible. Four is somehow a divine number.

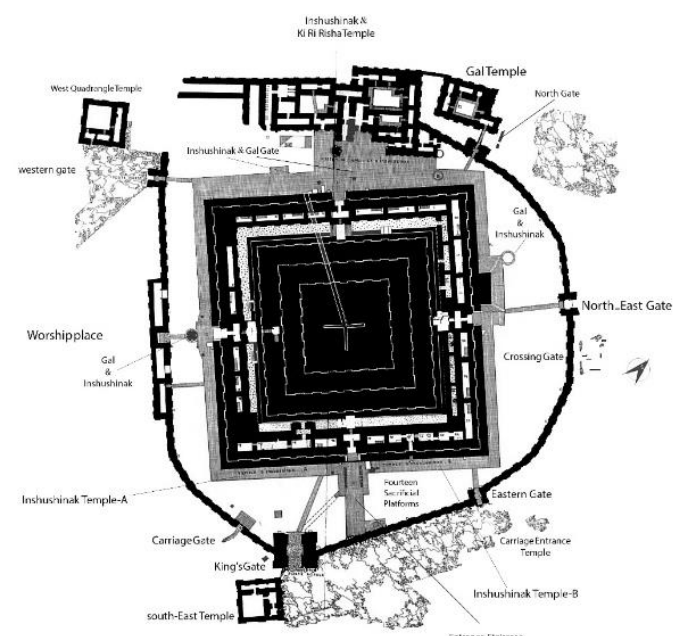

Fig 1. Plan of The Choga Zambil's Ziggurat (source: Fisher \& Shivers, 2008)

Number four can be observable in religious architecture a lot. The planes drawn from paradise are square-shaped (rectangular) and have four doors. The Choga Zambil's ziggurat has four entrance doors, and the directions of the ziggurat corners are matched to four main directions: the north, south, east and west. Finally, The Choga Zambil's ziggurat is surrounded by circular fences. The fence, the wall and the ring of rattles that cover the sacred places are among the oldest architectural structures of the shrines.

The shaped construction of the Ziggurat, Pyramids, Stupas, Pagodas and Mandala, all of which are considered sacred buildings, follows a similar idea. In all of these buildings, the tall buildings, rush from the ground to the sky and from the carpet to the throne, which is somehow reminiscent the mountains, and all of them, the sacred spaces, are portrayed are in the centre of the universe. According to the Islamic beliefs, in the "Mojmal altawarikh" (Bosworth, 1968) and other sources, it has been mentioned that the angels have brought the rocks of the Kaaba's home from the five holy mountains and have brought Hajar-Salood from Paradise. It is said the five mountains 
names like Mount Sinai, Mount of Olives, Mount Judi and Mount Hira. These mountains have been considered sacred because they are observable by God and the prophets came to them: like Mosa and Mount Sinai, Noah and Mount Judy, Isa and Mount of Olives, Muhammad and Mount Hira.

In fact, the ziggurats, pagodas and stupas were everywhere symbolic of the mountains and the sky. The people who came from the eastern land and lived in the plains, could not bring their peaks to the new land, so in the flat ground of the Middle East, they placed large ziggurat instead of holy mountains (fig. 2). The temple's likeness to the cosmic mountains has a special place in Babylonian culture, and this characteristic can be seen in the shape of their ziggurat, which saw the ascent of it, is reach to the summit of the universe, the stairways to heaven. The ziggurat or ziggurat word is taken from the Acedi, Zegharoo meaning, lift or raised (Wales, 1953). Each floor is smaller than the lower floor; therefore, the facade of each side has a staircase form. This ziggurat was the place for keeping statues of gods and performing religious ceremonies. The highest temple on the highest floor of the ziggurat seems to keep the god statues of Napir and Inshushinak in this temple. There are stairs in the middle of each floor on the four sides of the ziggurat; gates block each of them. These stairs were the ways of going to higher classes (See fig 3).

In 640 BCE, Ashurbanipal, the powerful king of Assuyria, seized Elamite city. Elamian people died, and their government was destroyed, and the temple of Choga Zambil turned into a mountain. The holly mountain was formed from the complete destruction of the Dur Untash city or the historic site of Choga Zambil (fig.4). Elam has wiped off the page.
In 1935, the aerial photos of Anglo-Iranian Oil Company revealed the strange shape of the Choga Zambil hill. Experts believed that the hill could not be normal, and the hill would again be turned into a temple.

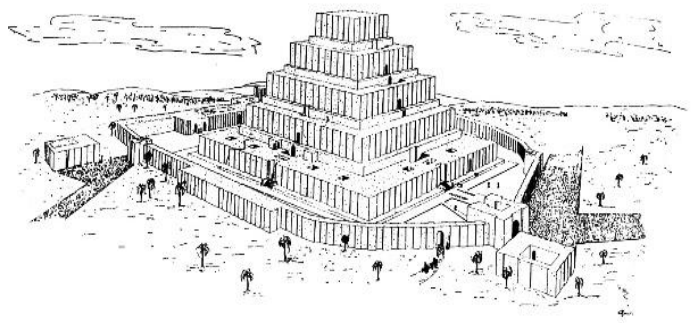

Fig 2. The image reconstruction of the skyline and Ziggurat in Khuzestan plain (source: Ghirshman, 1961)

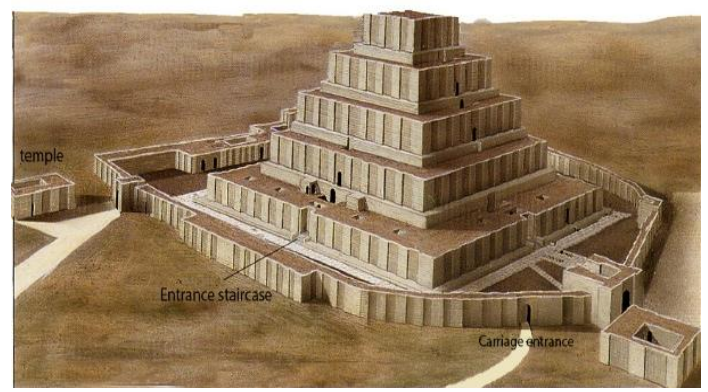

Fig 3. Entrances and stairways to heaven (source: Ghirshman, 1961)

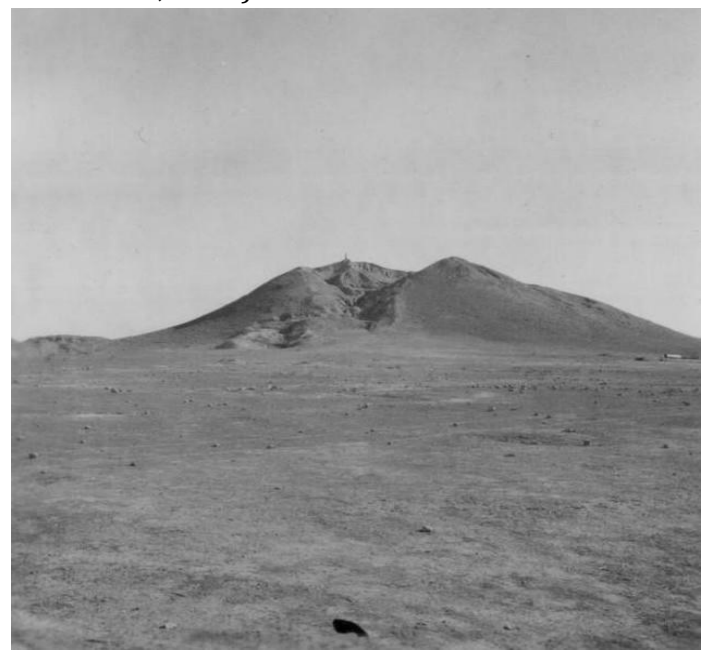

Fig 4. Memory experience or become original (source: Vafadari, 2008)

Man tries to create a sense of his/her lives and how man do this are subject to cross-question and doubt both from himself/herself and others, that she/he is mortal and know it, and that she/he wants her/his lives to be public as well as privately intelligible. However, more significantly, that the means available to 
make such sense are becoming increasingly imperfect, defective, faulty, malformed unreliable, and local (Wood, 2012). Choga Zambil is a sample for such a desire and such a mean. The city implicitly refers to a culture that the city is a symbol for the elimination of instability; in fact, the sign of the absence that it tries to present. The lost one, which is every time try to prove its presence.

In other words, symbols founded the city, which is the manifestation of the divine presence of the Dur Untash city, also are an attempt to overcome the fear of instability and death that is produced and reproduced by the city every moment and shows itself in an inexhaustible experience; A reaction against the feeling of instability and absenteeism and concealment and negation it; An attempt to A stable definition of self in the same deformation; consciously and unconsciously, a creation of a sustainability sense by symbols and concepts function.

What is certain is that no intelligible intuition of Dur Untash identity will do that fails to acknowledge, and Dur Untash city has become spiral even fractal. The Mountain idea, which was the symbol of the city, was the answer to their absence, away from them. Mountain idea returns to a mountain but in away from them, their lack. The city is described as a symbol of the world's order; the texture of the gates, walls, street order, the location of the city centre, and its nature are all aspects of the astrobiology (or the biological review of the supernatural beings). In this insight, sacredness is real, and as a result, only sacredness is safe. Natural complexes and buildings are similar to their stellar examples, and they must be sacred before making up as a living space; and this could be done by establishing a connection between heaven, earth, and the underworld. The city wants to be lean to such things. It is pleasing, but what has been gathered as a city is only a fractalization act. The city wants to state that it is moving in a definite and stable framework. Even if it cannot create and induce it both internally and externally, it makes fractal so much to cover its identification and his confusion, a complicated process.

What the city and the people are looking for are rooted in the dreams and desires that the city is trying to fulfil. However, every compilation, any symbolism, and whatever the city tries to deny, continues at the same time in the city. The city was a fractal for men. Choga zanbill's painful image has been raised when we grasp things that make us gratification, for then we are afraid of anyone or anything that may take them away from us; at the moment, the roots of its symbolic concept collapse. As much as the symbolic concept roots are not deconstructed, psychological gatherings prevent psychological pain.

Until there are enthusiasm and hope, there is always a background of fear. After many years, it still also can be observed that Choga Zambil afraid of anyone/ anything that disturbs it and loose the accumulated known. Chains of known and compassed stimulus, and the past that has been given to live through the present. Where through labelling, naming, and remembering from time feeds-the memory of various experiences that have produced and reproduced names, labels, identifications. According to the memory of the incident, have been determined to be or not to be. When the experience was gained, it is over; it is dead. It cannot be repeated. What can be repeated is the sensation and the corresponding word that gives life to that sensation. However, what is the difference between the two for 
Choga Zambil: life or life sensation (death) (fig. 5)?

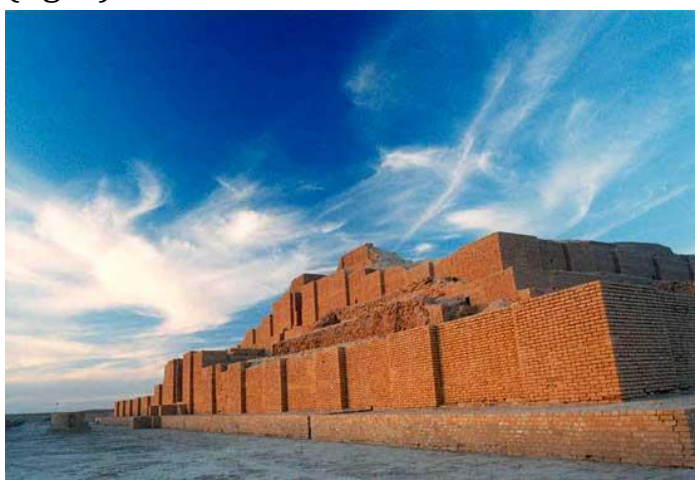

Fig. 5. life or life sensation

Choga Zambil seems to be very humble and simple, but inwardly it is prisoners. Now, what has left of it, except memory? A memory that follows a pattern of authority still likes to stay alive by showing the numerous impediments, attachments, fears, dreams, and ideas. What the play of its death is; a mechanical process of excitement and memory. That it is sensation and desire, and that it is mechanically caught up in the routine.

A constant state of denial and assertion, a continuous fight to become something apart from what it is. This is Dur Untash city, and it wants to be that (Ideal), a play of This \& That. An exciting process is seen in each element that including memorizing something and trying to overlook it in order to find something new. That is to say; there is a chase overcoming another chase-a seemingly permanent state which is being resisted by another temporary state. Choga Zambil is a means to such an outcome, and until the time comes, contradiction continues.

\section{Conclusion}

As monuments for find truth to achieve permanent gratification or a symbol for seeking lasting satisfaction, not for seeking the truth. Choga Zambil is a cover with an idea, a respectable-sounding word for that fleeting pleasures and unflattering delusion. In return, such contradiction gives us motivation and push to live; every resistance symbols creates a sense that life goes on; a sense of vitality. Finally, Choga Zambil is simply the crystallization of an idea as a symbol, and the effort to live up to the sign brings about a contradiction. A play is of concern with pleasure, and the avoidance of pain and its capacity' is to try to create such an image; the simultaneous presence of pain and pleasure.

\section{Funding statement}

The author state there is no conflict of interest related to funding in this study

\section{Acknowledgement}

The author would like to thank all those who supported this study to be carried out.

\section{References}

Abbinnett, R. (2003). Culture and Identity: Critical Theories. SAGE.

Anandarajan, M., Hill, C., \& Nolan, T. (2018). Practical Text Analytics: Maximizing the Value of Text Data. Springer.

Barthes, R. (1968). Elements of Semiology. Farrar, Straus and Giroux.

Barthes, R. (1994). The Semiotic Challenge. University of California Press.

Bennington, G., \& Derrida, J. (1993). Jacques Derrida. University of Chicago Press.

Bosworth, C. E. (1968). The Development of Persian Culture under the Early Ghaznavids. Iran, 6(1), 33-44. https://doi.org/10.1080/05786967 .1968 .11834438

Britannica. (2018). In Encyclopedia Britannica. Creative Media Partners, LLC.

Bryce, T. (2009). The Routledge Handbook of the Peoples and Places of Ancient Western Asia: From the Early Bronze Age to the Fall of the Persian Empire. Taylor \& Francis.

D'Cruz, C. (2016). Identity Politics in Deconstruction: Calculating with the Incalculable. Routledge.

Evans, J. C. (1991). Strategies of Deconstruction: Derrida and the Myth of the Voice. University of Minnesota Press. 
Fisher, D., \& Shivers, O. (2008). Building language towers with Ziggurat. Journal of Functional Programming, 18(5-6), 707-780. https://doi.org/10.1017/S0956796 808006928

Freshwater, D., \& Rolfe, G. (2004). Deconstructing Evidence Based Practice. Psychology Press.

Gabriel, F. (2013). Deconstructing Youth: Youth Discourses at the Limits of Sense. Springer.

Ghirshman, R. (1961). The Ziggurat of Tchoga-Zanbil. Scientific American, 204(1), 68-77. JSTOR. https://doi.org/10.2307/24940741

Gieseking, J. J., Mangold, W., Katz, C., Low, S., \& Saegert, S. (2014). The People, Place, and Space Reader. Routledge.

Gottdiener, M., \& Lagopoulos, A.-P. (1986). The City and the Sign: An Introduction to Urban Semiotics. Columbia University Press.

Harvey, D. (1970). Social Processes and Spatial Form: An Analysis of the Conceptual Problems of Urban Planning. Papers in Regional Science, 25(1), 47-69. https://doi.org/10.1111/j.14355597.1970.tb01477.x

Harvey, D. (2010). Social Justice and the City (Vol. 1). University of Georgia Press.

Hurst, A. M. (2008). Derrida Vis-à-vis Lacan: Interweaving Deconstruction and Psychoanalysis. Fordham University Press.

Keller, S. (1988). Review of The City and the Sign: An Introduction to Urban Semiotics [Review of Review of The City and the Sign: An Introduction to Urban Semiotics, by Mark Gottdiener \& A. Ph. Lagopoulos]. Contemporary Sociology, 17(3), 346-348. https://doi.org/10.2307/2069642

Knox, P. L. (1984). Symbolism, Styles and Settings. Architecture and Behaviour, 2(2), 107-122. https://www.epfl.ch/labs/lasur/w pcontent/uploads/2018/05/KNOX.p df
Krampen, M. (2013). Meaning in the Urban Environment. Routledge.

Kyngäs, H., Mikkonen, K., \& Kääriäinen, M. (2019). The Application of Content Analysis in Nursing Science Research. Springer Nature.

Lacey, A. (2002). Dictionary of Philosophy. Routledge.

Lagasse, P. (Ed.). (2003). The Columbia encyclopedia (Sixth edition). Columbia University Press.

Morris, A. E. J. (2013). History of Urban Form Before the Industrial Revolution (3rd Edition). Routledge.

Naas, M. (2003). Taking on the Tradition: Jacques Derrida and the Legacies of Deconstruction. Stanford University Press.

Nas, P. J. M. (2016). Cities Full of Symbols: A Theory of Urban Space and Culture. Leiden University Press.

Norris, C., \& Roden, D. (2003). Jacques Derrida (Vol. 4). SAGE.

Osborne, J. F. (2014). Approaching Monumentality in Archaeology. SUNY Press.

Payne, M. (1993). Reading Theory: An Introduction to Lacan, Derrida and Kristeva. Wiley.

Pipkin, J., Gory, M. L., \& Blau, J. R. (1983). Remaking the City. SUNY Press.

Potts, D. T. (2006). Elamites and Kassites in the Persian Gulf. Journal of Near Eastern Studies, 65(2), 111-119. https://doi.org/10.1086/504986

Richter, D. (2010). The $A$ to $Z$ of Wittgenstein's Philosophy. Scarecrow Press.

Rohl, D. M. (1999). Legend: The Genesis of Civilisation. Arrow.

Seasoltz, R. K. (2005). A Sense of the Sacred: Theological Foundations of Christian Architecture and Art. A\&C Black.

Sellers, S. (2003). The Hélène Cixous Reader. Routledge.

Staten, H. (1986). Wittgenstein and Derrida. University of Nebraska Press.

Stocker, B. (2006). Routledge Philosophy Guidebook to Derrida on Deconstruction. Routledge.

Vafadari, A. (2008). Visitor Management, the Development of Sustainable 
Cultural Tourism and Local Community Participation at Chogha Zanbil, Iran. Conservation and Management of Archaeological Sites, 10(3), 264-304. https://doi.org/10.1179/17535520 9X452804

Wales, H. G. Q. (1953). The Sacred Mountain in the Old Asiatic Religion. Journal of the Royal Asiatic Society of Great Britain and Ireland, 1/2, 2330. JSTOR. https://doi.org/10.2307/25222606

Williams, M. (2001). Problems of Knowledge: A Critical Introduction to Epistemology. Oxford University Press.

Wittgenstein, L. (2010). Philosophical Investigations. John Wiley \& Sons.

Wood, D. (1992). Derrida: A Critical Reader. Wiley.

Wood, D. (2012). Step Back, The: Ethics and Politics after Deconstruction. SUNY Press.

Wood, D., \& Bernasconi, R. (1988). Derrida and Différance. Northwestern University Press. 